\title{
KARAKTER MOLEKULER CHRYSANTHEMUM B CARLAVIRUS (CVB) ISOLAT KRISAN (DENDRANTHEMA GRANDIFLORA KITAM) DI INDONESIA
}

\author{
I G. R. M. Temaja ${ }^{1}$, G. Suastika ${ }^{2}$, S.H. Hidayat ${ }^{2} \&$ U. Kartosuwondo ${ }^{2}$
}

\begin{abstract}
Molecular characterstics of Chrysanthemum B Carlavirus (CVB) isolated from chrysanthemum (Dendranthema grandiflora Kitam) in Indonesia. Chrysanthemum B Carlavirus (CVB) belongs to Carlavirus genus which type species is Carnation latent virus (CLV). Since CVB is considered a new plant virus in chrysanthemum plantation in Indonesia, a study on its molecular characters is required. The objectives of the study are: 1) to determine molecular characters of CVB; 2 ) to study genetic diversity among CVB isolates collected from different geographic regions in Indonesia. The research activities cover virus purifications, electron microscope observation, coat protein analysis by SDS PAGE, and nucleic acid analysis. The result of virus purification demonstrated a high purity level with ratio value of $A_{260} / A_{280}$ $=1.22$. The total pure virus produced from $200 \mathrm{~g}$ of fresh material is $6.250 \mathrm{mg}$. Purified virus preparation yielded rather straight rod and flexuous virus particles of about $685 \mathrm{~nm}$ long and $12 \mathrm{~nm}$ wide. Coat protein analysis with sodium dodecyl sulphate-polyacrylamide gel electrophoresis (SDS-PAGE) showed specific protein band of approximately 34 kDa. Specific DNA fragment of 739 bp was successfully amplified from chrysanthemum infected by CVB Cianjur, Medan, Malang and Bali isolates. CVB isolated from Cianjur, Medan, Malang and Bali have similarity 85-99\%. Based on analysis using PAUP 4.10 program, Cianjur, Medan, Malang and Bali isolates belong to the same group with CVB isolates originated from India (Chattisgarh and Jammu isolates). Cianjur isolate has close relationship to Medan isolate, however Bali isolate showed a close relationship with Malang isolate.
\end{abstract}

Key words: Chrysanthemum B Carlavirus (CVB), molecular character, chrysanthemum

\section{PENDAHULUAN}

Krisan (Dendranthema grandiflora Kitam) adalah salah satu jenis bunga yang banyak diminati oleh masyarakat dunia, dan pada pasar bunga potong internasional krisan menempati urutan ketiga (Singh, 2000). Perbanyakan bahan tanaman krisan terutama secara vegetatif (stek). Hal ini memberikan kesempatan yang sangat baik bagi virus, sebagai parasit obligat, untuk menyebar secara luas bersamaan dengan penyebaran bahan tanaman tersebut. Chrysanthemum B Carlavirus (CVB) adalah virus utama yang menginfeksi krisan dan dilaporkan telah tersebar pada pertanaman krisan di seluruh dunia. Infeksi virus ini pada tanaman krisan menyebabkan gejala motling atau vein-clearing yang sangat mild pada daun, serta penurunan kualitas bunga (Hollings \& Stones, 1972; Verma et al. 2003).

CVB termasuk dalam genus Carlavirus yang anggotanya dicirikan dengan tipe Carnation latent virus (CLV). Anggota Carlavirus memiliki partikel bentuk batang agak lentur dengan ukuran panjang 610-700 nm dan diameter 12-15 nm. Virion mengandung molekul RNA tunggal linier dalam bentuk positive-sense utas tunggal (positive-sense ssRNA), panjangnya 7,4-8,5 nm, dan memiliki polyadenilate (poly-A) pada ujung 3'. Asam nukleatnya diselubungi oleh protein selubung tunggal dengan berat 31-36 kDa (Lee et al., 2003; Zavriev et al., 1991; Lawrence et al., 1995; Fauquet et al., 2005).

CVB memiliki partikel berbentuk batang agak lurus dan lentur, dengan ukuran 680-685 nm x 12-13 nm. Partikel lebih lurus dan kelihatan kurang lentur dibandingkan CLV, dan cenderung terputus-putus bila dilakukan pengecatan dengan phosphotungstate (Hollings \& Stone, 1972; Suastika et al., 1997; Verma et al., 2003).

Pengamatan bentuk dan panjang partikel virus serta ukurannya, umumnya dilakukan terhadap siapan virus murni yang didapat dari hasil pemurnian virus tersebut. Berbagai modifikasi prosedur pemurnian suatu virus telah banyak dikembangkan yang disesuaikan dengan sifat dan jenis virusnya (Matthews, 1992). Hasil pemurnian virus dapat diamati dengan sodium dodecyl sulphatepolyacrylamide gel electrophoresis (SDS-PAGE)

\footnotetext{
${ }^{1}$ Jurusan Hama dan Penyakit Tumbuhan, Fakultas Pertanian, Univesitas Udayana, e-mail: gederaimaya@yahoo.com

${ }^{2}$ Departemen Proteksi Tanaman, Fakultas Pertanian, Institut Pertanian Bogor, Jl. Kamper, Kampus Darmaga, Bogor 16680
} 
untuk mengetahui berat molekul protein selubung virus.

Karakterisasi molekul virus tanaman dapat dilakukan juga melalui sifat asam nukleat virus tersebut. Saat ini metode deteksi dan identifikasi virus yang akurat banyak dilakukan berbasis pada pengetahuan biologi molekuler yang telah berkembang sangat pesat. Teknik PCR (Polymerase Chain Reaction) merupakan cara cepat untuk mengamplifikasi DNA secara in vitro, sangat berguna dalam mengidentifikasi virus yang menginfeksi tanaman, hewan dan manusia. Gen protein selubung dan ujung 3' untranslated region (UTR) banyak digunakan peneliti sebagai dasar untuk identifikasi, studi keragaman dan analisis filogenetika Carlavirus. Perunutan asam nukleat dapat pula digunakan untuk mengetahui keragaman dan hubungan kekerabatan antar strain virus. Umumnya tingkat keragaman dapat diketahui berdasarkan gen penyandi selubung protein virus. Pengelompokan dan hubungan kekerabatan ditentukan berdasarkan tingkat kesamaan urutan susunan asam nukleat.

Walaupun karakter molekuler CVB telah dilaporkan tetapi informasi mengenai hal yang sama belum tersedia untuk CVB yang dilaporkan oleh Temaja et al. (2007) menginfeksi tanaman krisan di Indonesia. Penelitian dilakukan untuk mengetahui karakter molekuler CVB isolat Indonesia yaitu melalui pengamatan di bawah mikroskop elektron untuk mengamati ciri-ciri morfologi partikel virus, melalui analisis SDS-PAGE untuk mengetahui ciri protein selubung virus, dan melalui perunutan DNA untuk mengetahui keragaman genetik isolat virus.

\section{METODE PENELITIAN}

Penelitian ini dilaksanakan di Laboratorium Virologi Tumbuhan dan Rumah Kaca Cikabayan, Departemen Proteksi Tanaman, Fakultas Pertanian, IPB, berlangsung dari bulan April 2007 hingga bulan Agustus 2007.

Perbanyakan virus pada tanaman inang. Percobaan ini menggunakan CVB isolat Cianjur, dan inang perbanyakannya adalah tanaman Nicotiana benthamiana. Tanaman umur tiga minggu diinokulasi secara mekanis dengan sap tanaman $N$. benthamiana yang terinfeksi CVB dalam bufer fosfat 0,01 M, pH 7,0 (1:5 b/v). Setelah 17 hari dari saat inokulasi, daun dan ranting tanaman dipanen untuk pemurnian virus.

Pemurnian virus. Metode pemurnian CVB dilakukan sesuai dengan prosedur dari Foster (1998) menggunakan $200 \mathrm{~g}$ daun tanaman N. benthamiana terinfeksi CVB. Tingkat kemurnian virus diukur menggunakan spektrofotometer pada panjang gelombang $260 \mathrm{~nm}\left(\mathrm{~A}_{260}\right)$ dan $280 \mathrm{~nm}\left(\mathrm{~A}_{280}\right)$. Perbandingan antara nilai $\mathrm{A}_{260} / \mathrm{A}_{280}$ dapat digunakan untuk mengetahui tingkat kemurnian virus (Dijkstra \& de Jager, 1998). Berdasarkan nilai $\mathrm{A}_{260}$ dan extinction coefficient $\left(\mathrm{E}_{1 \mathrm{~cm} .260 \mathrm{~nm}}^{0.1 \%}\right)$ carlavirus 2,3 (Koenig, 1982) dapat dihitung konsentrasi virus.

Pengamatan morfologi virus dengan mikroskop elektron. Lempeng tembaga (grid) berukuran 400 mesh yang telah dilapisi colodion dan diberi serbuk karbon dicelupkan ke dalam siapan virus. Siapan virus tersebut sebelumnya telah dilarutkan pada larutan 2\% PTA (Sodium phosphotungstate) $\mathrm{pH}$ 7,0 pada gelas objek selama 5 menit kemudian dikeringkan menggunakan kertas blotter. Siapan virus yang menempel pada lempeng tembaga diamati di bawah mikroskop elektron (JEOL 1010, Japan) yang dioperasikan pada $80 \mathrm{kV}$.

SDS-PAGE dan Western Blot. Berat molekul protein selubung tunggal (sub unit partikel selubung) virus ditentukan dengan sodiom dodecyl sulphatepolyacrylamide gel electrophoresis (SDS-PAGE). Running buffer dan gel (4,5\% stacking gel dan 12,5\% separating gel) disiapkan mengikuti metode Leammli (Gall et al., 1980).

Siapan virus murni dan protein tanaman total masing-masing ditambah loading dye (SDS 4\%, 2mercaptoethanol 2\%, bromophenol blue 0,001\%, glycerol 2\% dan Tris-HCl 0,1 M, pH 8,8) dengan perbandingan $1: 4(\mathrm{v} / \mathrm{v})$, dipanaskan pada suhu $100{ }^{\circ} \mathrm{C}$ selama 10 menit dan kemudian masing-masing $15 \mu \mathrm{l}$ campuran tersebut dimasukkan ke dalam sumuran gel.

Elektroforesis pada $80 \mathrm{~V}$ selama 3 jam, protein divisualisasi dengan pewarnaan Coomassie Blue (BioRad Laboratories, USA). Gel direndam dalam asam asetat glasial $12,5 \%$ selama 5 menit kemudian direndam dalam larutan Coomassie blue 0,25\% dan diinkubasi selama 12 jam di atas shaker. Gel dicuci menggunakan larutan penghilang warna yang terdiri atas metanol 50\% dan larutan asam asetat $10 \%$ sebanyak 3 x 10 menit. Pengujian Western Blot 
dilakukan berdasarkan metode Towbin et al. (1979) menggunakan antiserum CVB.

Karakter molekuler CVB berdasarkan perunutan DNA. Perunutan DNA virus dilakukan melalui tahapan ekstraksi RNA, amplifikasi DNA, dan perunutan (sekuensing) DNA terhadap masing-masing sampel dari Medan, Cianjur, Malang dan Bali. Total RNA diekstraksi dari jaringan daun tanaman krisan menggunakan Rneasy Plant Mini Kits (Qiagen, Germany). Amplifikasi sebagian genom CVB dilakukan dengan teknik Reverse Transcription-PCR (RT-PCR) menggunakan pasangan primer CVB5 (5'CAAAGAGGTGATCATCCGTCTAG3') (forward primer) dan CVB3 (5'CTCGGTTAC TTTATCGCACCTAG3') (reverse primer) dengan ukuran produk 739 bp. Primer diperoleh dari Plant Virus GenBank, Soul Women's University. Amplifikasi dilakukan pada Gene Amp PCR System 9700 thermocycler.

Reaksi RT sebanyak $25 \mu \mathrm{l}$ terdiri dari $3 \mu \mathrm{l}$ template RNA, $1.3 \mu \mathrm{M}$ reverse primer, $0.2 \mathrm{mM}$ dNTP, $1 \mathrm{x}$ bufer RT, 200 unit enzim reverse transcriptase MMuLV (New England BioLabs), 40 unit Recombinant RNasin Ribonuclease Inhibitor (Promega, Madison, WI, USA), dan Reaksi RT dilakukan pada kondisi $25^{\circ} \mathrm{C}$ selama 5 menit, $37^{\circ} \mathrm{C}$ selama 90 menit, diikuti dengan inaktivasi pada $72{ }^{\circ} \mathrm{C}$ selama 15 menit.

Reaksi PCR sebanyak $25 \mu \mathrm{l}$ terdiri dari $3 \mu \mathrm{l}$ template cDNA, 0,4 mM masing-masing primer, $1 \mathrm{x}$ bufer PCR, $0.2 \mathrm{mM}$ dNTP dan 1 unit taq DNA polimerase (New England BioLabs). Amplifikasi dilakukan 35 siklus yang melalui tiga tahapan yaitu pemisahan utas DNA pada $94^{\circ} \mathrm{C}$ selama 30 detik, penempelan primer pada $45{ }^{\circ} \mathrm{C}$ selama 1 menit, dan sintesis DNA pada $72^{\circ} \mathrm{C}$ selama 1 menit. Khusus untuk siklus terakhir ditambah tahapan sintesis selama 10 menit, kemudian siklus berakhir dengan suhu $4^{\circ} \mathrm{C}$ (Ram et al. 2005).

Produk PCR dielektroforesis pada gel agarose $1,2 \%$ yang dijalankan pada $80 \mathrm{~V}$ selama 1 jam. Gel diwarnai dalam $2 \mu \mathrm{g} / \mathrm{ml}$ ethidium bromida dalam buffer elektroforesis (bufer TAE) dan divisualisasi pada UV transluminator.

Fragmen DNA hasil amplifikasi genom CVB dirunut untuk melihat susunan nukleotida DNA masing-masing isolat yang ditemukan. Hasil runutan kemudian dianalisis tingkat kesamaannya menggunakan software Blast2.Wu yang terdapat dalam situs the European Bioinformatic Institute (EBI) (www.ebi.ac.uk).

Analisis kekerabatan dilakukan terhadap isolatisolat CVB yang ditemukan dan dibandingkan dengan sekuen genom CVB lain yang ada di GeneBank (www.ncbi.nml.nih.gov). Analisis filogenetika dilakukan dengan menggunakan program PAUP (PAUP version $4.0 b 10$ for 32-bit Microsoft Windows) berdasarkan pendekatan Unweighted Pair Group Method with Arithmetic Mean (UPGMA).

\section{HASIL DAN PEMBAHASAN}

Pemurnian dan karakterisasi virus. Pemurnian CVB mendapatkan zona virus yang membentuk suatu pita (band) yang berbatas tegas yang mencerminkan

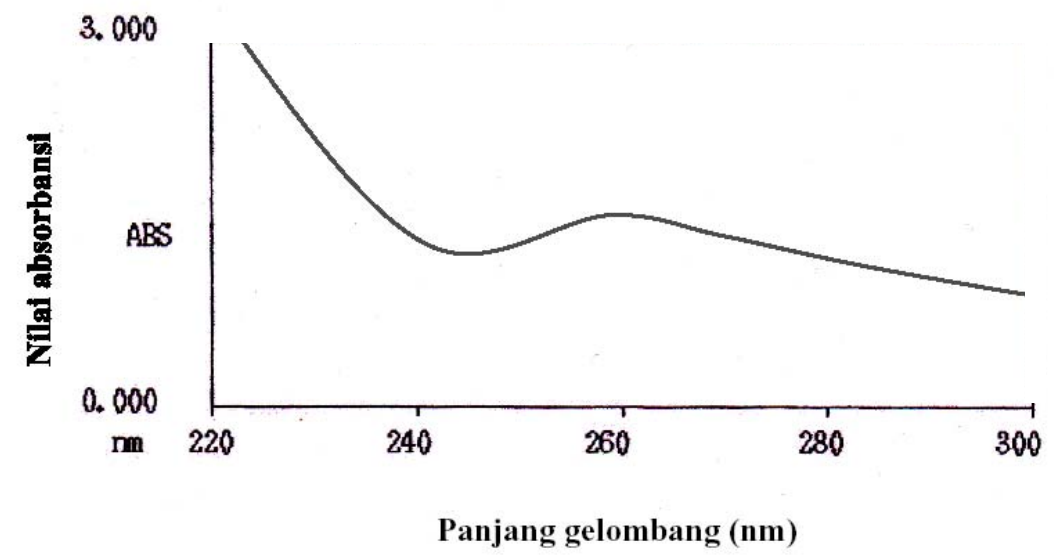

Gambar 1. Nilai absorbansi virus murni. 
lokasi virus berada. Spektrofotometri terhadap suspensi virus murni yang diambil dari pita zona virus menghasilkan nilai absorbansi pada panjang gelombang $260 \mathrm{~nm}\left(\mathrm{~A}_{260}\right)$ adalah 1,449 dan pada $\mathrm{A}_{280}$ adalah 1,183 (Gambar 1). Tingkat kemurnian virus dapat dihitung dari nisbah $\mathrm{A}_{260} / \mathrm{A}_{280}$ yaitu 1.22. Nilai nisbah ini menunjukkan suspensi virus murni hasil purifikasi pada penelitan ini mempunyai tingkat kemurnian yang cukup tinggi. Dijkstra \& de Jager (1998) menyatakan bahwa virus dengan bentuk partikel memanjang memiliki nilai $\mathrm{A}_{260} / \mathrm{A}_{280}$ sekitar 1,2; sedangkan virus dengan bentuk partikel isometrik memiliki nilai $\mathrm{A}_{260} / \mathrm{A}_{280}$ sekitar 1,7. Keberhasilan pemurnian tersebut mungkin disebabkan oleh faktor metode yang digunakan yang lebih sederhana dan mudah sehingga memperkecil terjadinya proses oksidasi. Semakin cepat dan sederhana metode yang digunakan, degradasi virus karena proses oksidasi makin diperkecil sehingga diperoleh partikel virus dengan konsentrasi tinggi dan tidak rusak.

Berdasarkan asumsi extinction coefficient $\left(\mathrm{E}_{1 \mathrm{~cm} .260 \mathrm{~nm}}^{0.1 \%}\right)$ carlavirus 2,3, maka konsentrasi virus pada suspensi virus murni tersebut adalah 0,630 $\mathrm{mg} / \mathrm{ml}$. Jadi total virus yang dihasilkan dari $200 \mathrm{~g}$ daun segar $N$. benthamiana adalah 6,250 mg.

Pemurnian CVB menggunakan tanaman $N$. clevelandii sebagai tanaman propagasi dan pemurnian melalui sentrifugasi gradien sukrose Suastika et al. (1997) memperoleh nilai $\mathrm{A}_{260} / \mathrm{A}_{280}$ sebesar 1,3 dan $12 \mathrm{mg}$ virus murni per $100 \mathrm{~g}$ daun segar. Sedangkan Hollings \& Stone (1972) melaporkan bahwa nilai $\mathrm{A}_{260} / \mathrm{A}_{280} \mathrm{CVB}$ adalah 1,55.
Pengamatan morfologi virus dengan mikroskop elektron. Hasil pengamatan dengan mikroskop elektron terhadap virus murni menunjukkan adanya partikel virus yang berbentuk batang agak lurus dan lentur dengan ukuran panjang 685 nm dan lebar 12 nm (Gambar 2). Bentuk dan ukuran partikel virus ini sesuai dengan yang dilaporkan oleh peneliti terdahulu. Hollings \& Stone (1972) mendapatkan bentuk dan ukuran partikel CVB yang sama dengan hasil pengamatan pada penelitian ini. Suastika et al. (1997) pada pengamatan siapan murni CVB menemukan partikel virus berbentuk panjang agak lentur dengan ukuran panjang 650-700 nm dan lebar 13 nm; dan pengamatan Verma et al. (2003) juga mendapatkan bentuk partikel lentur dengan ukuran 680x12 nm.

Analisis SDS - PAGE dan Western Blot. Analisis SDS-PAGE menunjukkan adanya pita yang sama pada sampel daun $N$. benthamiana terinfeksi CVB dan virus murni yaitu pita protein berukuran sekitar 34 kDa (Gambar 3A), dan pita tersebut tidak nampak pada sampel daun $N$. benthamiana sehat. Hal ini menunjukkan pita tersebut adalah protein selubung dari virus. Konfirmasi dengan analisis Western blot terhadap protein selubung virus menggunakan antiserum CVB menunjukkan bahwa pita protein berukuran $34 \mathrm{kDa}$ bereaksi positif dengan antiserum CVB (Gambar 3B). Ini berarti bahwa memang benar pita dengan berat molekul $34 \mathrm{kDa}$ tersebut adalah protein selubung CVB. Hasil ini sesuai dengan laporan peneliti sebelumnya yang menemukan berat molekul protein selubung CVB adalah $34 \mathrm{kDa}$ (Suastika et al., 1997).

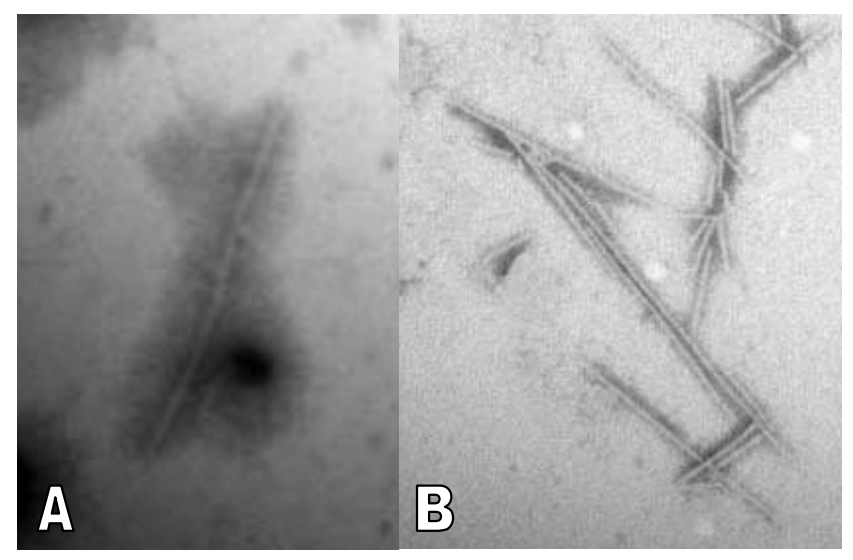

Gambar 2. Bentuk partikel CVB pada mikroskop elektron (pembesaran 40.000 kali) yang preparasinya berupa sap tanaman terifeksi CVB (A) dan virus murni (B). 

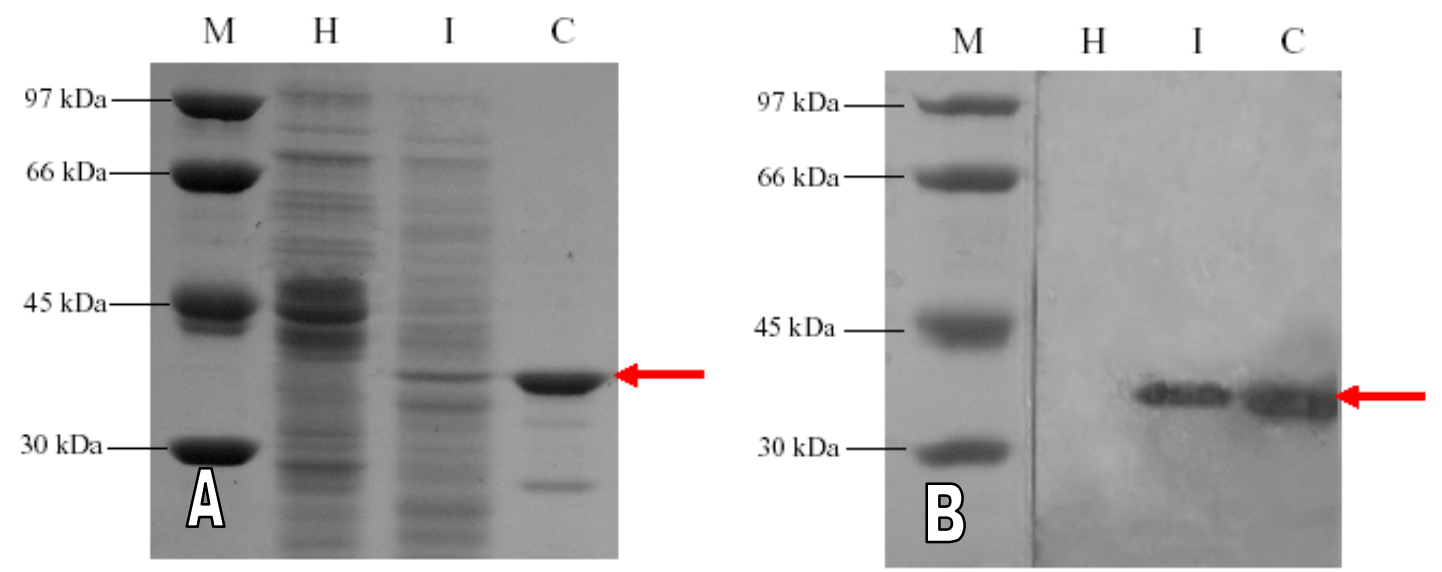

Gambar 3. Hasil analisis SDS-PAGE (A) dan western blot (B) protein selubung CVB isolat Cianjur. Keterangan: (M) Marker , (H) daun N. benthamiana sehat, (I) daun N. benthamiana terinfeksi CVB dan (C) virus murni.

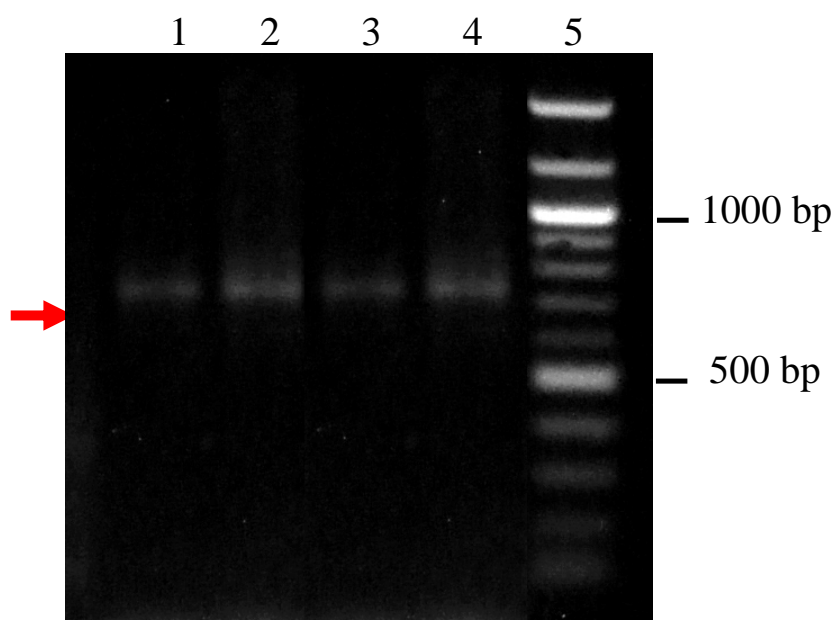

Gambar 4. Hasil amplifikasi DNA CVB dengan metode RT-PCR menggunakan sepasang primer CVB 5 dan CVB 3. Lajur 1,2,3 dan 4 menunjukkan hasil amplifikasi ( 739 bp) isolat Medan, Cianjur, Malang dan Bali. Lajur 5: penanda DNA.

Perunutan DNA CVB. Amplifikasi dengan teknik RT-PCR menggunakan primer CVB 5 dan CVB 3 berhasil mendapatkan fragmen DNA berukuran 739 bp dari sampel daun asal Medan, Cianjur, Malang dan Bali (Gambar 4). Ukuran fragmen DNA tersebut sesuai dengan yang diharapkan berdasarkan analisis sekuen primer di Plant Virus GenBank, Soul Women's University. Hasil analisis 4 isolat CVB dengan clustalW menunjukkan bahwa ada beberapa bagian gen selubung protein yang memiliki homologi.
Isolat CVB Cianjur, Medan, Malang dan Bali mempunyai tingkat kesamaan (similarity) $80-87 \%$, 79-86\%, 85-95\%, dan 84-94\% dengan sekuen CVB lainnya yang ada di GeneBank (Table 1). Isolat Cianjur ditemukan memiliki tingkat kesamaan masing-masing 99\%, 87\% dan 85\% terhadap isolat Medan, Malang dan Bali. Isolat Malang memiliki tingkat kesamaan masing-masing 98\% dan 86\% terhadap isolat Bali dan Medan. Sedangkan isolat Bali hanya memiliki tingkat kesamaan 85\% terhadap isolat 
Table 1. Tingkat kesamaan isolat CVB yang berasal dari geografi berbeda berdasarkan sekuen gen protein selubung

\begin{tabular}{|c|c|c|c|c|c|c|c|c|c|c|c|c|c|c|c|}
\hline \multirow[t]{2}{*}{ No } & \multirow[t]{2}{*}{ Isolat } & \multirow[t]{2}{*}{ No. aksesi } & \multicolumn{13}{|c|}{ Tingkat kesamaan (\%) } \\
\hline & & & 1 & 2 & 3 & 4 & 5 & 6 & 7 & 8 & 9 & 10 & 11 & 12 & 13 \\
\hline 1 & Ind:Maharashtra & AJ581993 & - & & & & & & & & & & & & \\
\hline 2 & Ind:Chattisgarh & AM039442 & 88 & - & & & & & & & & & & & \\
\hline 3 & Ind:Jammu & AJ812569 & 90 & 96 & - & & & & & & & & & & \\
\hline 4 & Ind:Sikkkim & AJ585514 & 99 & 89 & 91 & - & & & & & & & & & \\
\hline 5 & Ind:Tamilnadu 2 & AJ582016 & 85 & 85 & 85 & 85 & - & & & & & & & & \\
\hline 6 & Ind:Tamilnadu 1 & AJ585051 & 91 & 88 & 89 & 91 & 94 & - & & & & & & & \\
\hline 7 & Ita:Mgh 57 & AY170324 & 90 & 94 & 95 & 91 & 84 & 89 & - & & & & & & \\
\hline 8 & Ind:Leh & AJ871367 & 92 & 95 & 96 & 92 & 86 & 91 & 97 & - & & & & & \\
\hline 9 & Ind:Arunachal P & AJ748852 & 82 & 83 & 82 & 82 & 86 & 80 & 82 & 83 & - & & & & \\
\hline 10 & Ina:Cianjur & - & 86 & 86 & 87 & 86 & 83 & 85 & 85 & 87 & 80 & - & & & \\
\hline 11 & Ina:Malang & - & 90 & 92 & 93 & 90 & 86 & 88 & 94 & 95 & 85 & 87 & - & & \\
\hline 12 & Ina:Bali & - & 88 & 90 & 91 & 88 & 85 & 87 & 92 & 94 & 84 & 85 & 98 & - & \\
\hline 13 & Ina:Medan & - & 85 & 85 & 86 & 85 & 82 & 84 & 84 & 86 & 79 & 99 & 86 & 85 & - \\
\hline
\end{tabular}

Keterangan: Ind = India, Ita = Italia, Ina = Indonesia

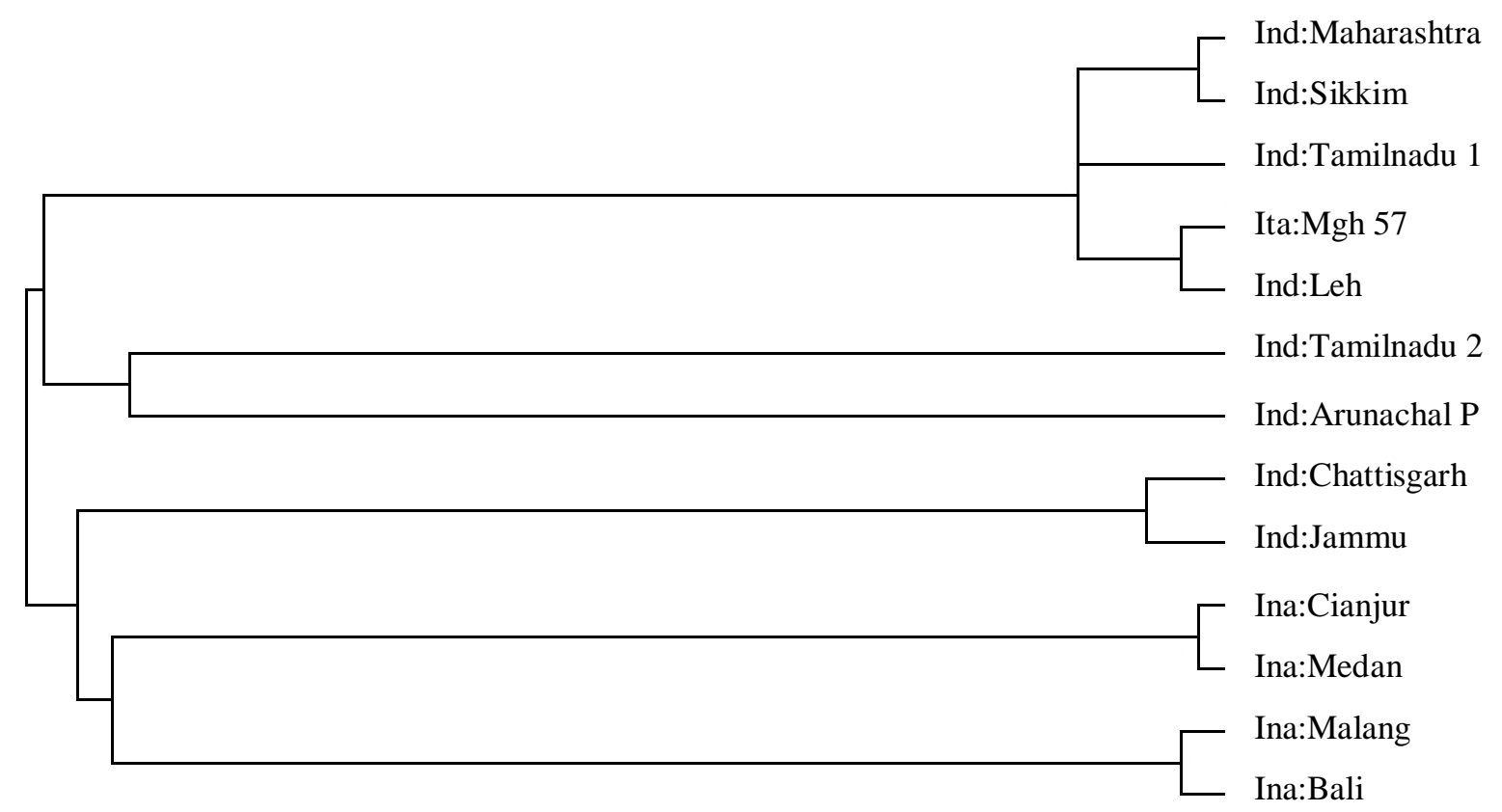

Temaja et al. : Karakter Molekuler Chrysanthemum B Carlavirus (CVB) lisolat Krisan di ndonesia

yang ada di GeneBank.

Keterangan: Ind = India, Ita = Italia, Ina = Indonesia 
hubungan yang dekat dengan tingkat kesamaan 99\%; dan isolat Bali memiliki hubungan dekat dengan isolat Malang dengan tingkat kesamaan 98\%.

Analisis filogenetik menggunakan program PAUP 4.10 menunjukkan bahwa isolat-isolat Indonesia termasuk dalam kelompok yang sama dengan CVB isolat Chattisgarh dan Jammu India (Gambar 5). Namun demikian isolat Indonesia terbagi lagi menjadi dua sub kelompok. Isolat CVB Cianjur dan Medan termasuk satu sub kelompok, dan isolat Bali dan Malang pada sub kelompok lainnya.

\section{SIMPULAN}

Morfologi partikel virus dan berat molekul protein selubung sesuai dengan morfologi partikel CVB yang dilaporkan oleh peneliti terdahulu. Urutan nukleotida CVB menunjukkan adanya keragaman genetik antara isolat-isolat CVB yang berasal dari daerah geografis yang berbeda di Indonesia. Isolat CVB Cianjur dan Medan berada dalam satu sub kelompok, sedangkan isolat Bali dan Malang pada sub kelompok yang berbeda.

\section{SANWACANA}

Penulis mengucapkan terima kasih kepada Prof. Dr. Murai, Utsunomiya University Japan, atas bantuan antiserumnya; dan Sdr. Tuti Susanti Legiastuti atas bantuan teknisnya dalam penelitian ini.

\section{DAFTAR PUSTAKA}

Badge, J., A. Brunt, R. Carson, E. Dagless, M. Karamagioli, M. Phillips, S. Seal, R. Turner, \& G. D. Foster. 1996. A carlavirus-specitic PCR primer and partial rnicleotidc sequence provides further evidence for the recognition of cowpea mild mottle virus as a whitefly-transmitted carlavirus. Eur. J. Plant Pathol. 102: 305310.

Chen, J., J.P. Chen, \& M.J. Adam. 2002. Characterization of some carla- and potyvirus from bulb in China. Arch. Virol. 147:419-428.

Cohen, J., M. Zeidan, A. Rosner, \& A. Gera. 2000. Biological and molecular characterization of a new carlavirus isolated from an Aconitum sp. Phytopathology 90:340-344.

Dijkstra, J. \& C.P. de Jager. 1998. Practical Plant Virology. Protocol and Exercises. SpringerVerlag Berlin Heidelberg, New York.

Fauquet, C.M., M.A. Mayo, J. Maniloff, U. Desselberger, \& L.A. Ball. 2005. Virus Taxonomy: Classification and Nomenclature of Viruses. Elsevier Acad. Press., Amsterdam.

Foster, G.D. 1998. Carlavirus isolation and RNA extraction. In: Foster,G.D., Taylor, S.C. (Eds.), Plant Virology Protocols, from Virus Isolation to Transgenic Resistance. Humans Press, Totowa, NJ, pp. 145-150.

Foster, G.D. \& P. R. Mills. 1992. The 3'-Nucleotide Sequence of an Ordinary Strain of Potato Virus S. Virus Gene 6(3): 213-220.

Fuji, S., H. Yamamoto, M. Inoue, K. Yamashita, Y. Fukui, H. Furuya, \& H. Naito. 2002. Complete nucleotide sequence of the genomic RNA of Aconitum latent virus (genus Carlavirus) isolated from Delphinium sp. Arch Virol 147: 865-870.

Gall, O., G.A. Medgyesi \& L. Vereskey. 1980. Electrophoresis in the Separation of Biological Macromolecules. John Willey Sons, New York.

Hataya, T., K. Uchino, R. Arimoto, N. Suda, T. Sano, E. Shikata, \& I. Uyeda. 2000. Molecular characterization of Hop latent virus and phylogenetic relationships among viruses closely related to carlaviruses. Arch Virol. 145: 2503-2524.

Hollings, M. \& O.M. Stone. 1972. Chrysanthemum virus B. CMI/AAB Description of Plant Viruses No. 110.

Koenig, R. 1982. Carlavirus group. CMI/AAB. Descriptions of Plant Viruses No. 259. 
Lawrence, D.M., M.N. Rozanov \& B.I. Hillman. 1995. Autocatalytic processing of the $223 \mathrm{kDa}$ protein of blueberry scorch carlavirus by papain-like proteinase. Virology 207: 127-135.

Lee, B.Y., S.H. Choi \& K.H. Ryu. 2003. Characterization of the 3'-terminal nucleotide sequence of two Korean isolates of Daphne virus $\mathrm{S}$ support its placement as a distinct species of the genus Carlavirus. Arch. Virol. 148:1915-1924.

Matthews, R.E.F. 1992. Fundamentals of Plant Virology. Academic Press Inc., California.

Ram, R., N. Verma, A.K. Singh, L. Singh, V. Hallan, \& A.A. Zaidi. 2005. Indexing and production of virus-free chrysanthemums. Biologia Plantarum 49(1):149-152.

Singh, H.P. 2000. Current status of floricultureNational and International Scenario. In: Singh, H.P., Dadlani, N.K. (Eds.), Commercial Floriculture. FAO and DAC, Ministry of Agriculture, Govt. of India, New Delhi, pp. 126.
Suastika, G. J. Kurihara, K.T. Natsuaki \& K. Tomaru. 1997. A strain of Chrysanthemum B carlavirus causing flower colour breaking on Gymnaster savatieri (Makino) Kitamura. Ann. Phytopathol. Soc. Jpn. 63:1-7.

Temaja, I.G.R.M., G. Suastika, S.H. Hidayat \& Kartosuwondo U. 2007. Deteksi Chrysanthemum B Carlavirus (CVB) pada Tanaman Krisan di Indonesia. Agritrop 26(1):612.

Towbin, H., T. Staehelin \& J. Gordon. 1979. Electrophoretic transfer of protein from polyacrylamide gels to nitrocellulose sheets: Procedure and some applications. Proc. Natl. Acad. Sci. USA 76:4350-4354.

Verma, N., A. Sharma, R. Ram, V. Hallan, A.A. Zaidi, \& I.D. Garg. 2003. Detection, identification and incidence of Chrysanthemum B carlavirus in chrysanthemum in India. Crop Protect. 22:415429.

Zavriev, S.K., K.V. Kanyuka \& K.E. Levay. 1991. The genome organization of potato virus $M$ RNA. J Gen Virol 72: 9-14. 